Emilia Denkiewicz-Szczepaniak

Uniwersytet Gdański

\title{
Działalność Poselstwa RP w Oslo w latach 1946-1947
}

The activity of the Polish Legation in Oslo, 1946-1947

The activity of the Polish Legation in Oslo in the years 1946-1947 is one of the most important and, at the same time, one of the most difficult periods in the history of Polish-Norwegian relations. The introduction explains the reasons for such a late sending of a Polish representative, Mieczysław Rogalski, to Norway. Section I presents the biography of Rogalski as well as the experience he gained while working for the Ministry of Foreign Affairs. The next section describes the negative attitude that the Polish diplomat had during his contacts with the Norwegian Ministry of Foreign Affairs (Utenriksdepartementet), especially in relation to further repatriation of Poles, which was started in autumn 1945 by the liaison officers of the Polish government in exile. Section III presents the diplomatic successes Rogalski had in his relations with Norwegian politicians and also indicates how good his orientation in Norway's foreign policy was. Finally, the last section contains a description of Legation problems regarding mutual exchange of decorations and orders between Poland and Norway, including in particular political activities connected with the organization of celebrations commemorating the victory at Narvik.

Key words: Legation of Poland, Oslo, Polish-Norwegian relations,

Mieczysław Rogalski, 1946-1947

Słowa klucze: Poselstwo RP, Oslo, stosunki polsko-norweskie,

Mieczysław Rogalski, 1946-1947

\section{Wprowadzenie}

Norwegia najdłużej ze wszystkich krajów skandynawskich, bo aż do kwietnia 1946 roku oczekiwała na przedstawiciela dyplomatycznego z Warszawy. Tuż po zakończeniu wojny polski rząd emigracyjny w Londynie podjął szybkie działania w celu utrzymania polskiej placówki dyplomatycznej w Oslo, chcąc nie dopuścić do ulokowania tam posła komunistycznego rządu z Warszawy i pragnąc zająć się ogromną rzeszą Polaków, którzy na skutek działań Trzeciej Rzeszy w Norwegii znaleźli się w tym kraju. W tym celu polski rząd emigracyjny wysłał do Oslo Wiesława Patka, sekretarza swego Poselstwa w Sztokholmie. Patek pojawił się w Oslo 
już 25 maja 1945 roku i zgodnie z instrukcjami ministra pełnomocnego w Sztokholmie Henryka Sokolnickiego miał szybko otworzyć poselstwo polskiego rządu emigracyjnego oraz objąć, w miarę możliwości, stanowisko charge d'affaires. Drugim ważnym zadaniem Patka było objęcie opieką Polaków rozmieszczonych latem i jesienią 1945 roku w 29 obozach repatriacyjnych na terenie Norwegii. W sumie po przeprowadzonej rejestracji w obozach tych znajdowało się 17287 Polaków, w tym 1041 jeńców wojennych, 12384 byłych żołnierzy Wehrmachtu, 3862 przymusowych robotników Organizacji Todt oraz 30 Polaków z terenów zajętych przez ZSRS (Denkiewicz-Szczepaniak 2014: 37-61; 2018b: 235-249). Jednakże akcja zorganizowania polskiej placówki przez rząd emigracyjny się nie powiodła, głównie na skutek interwencji ambasady sowieckiej w Oslo, która doprowadziła do tego, że 15 sierpnia 1945 roku Patek został zmuszony przez norweski MSZ do opuszczenia Norwegii (Denkiewicz-Szczepaniak 2018a: 207-210). Ponadto Norwegia już 6 lipca 1945 roku uznała powołany 28 czerwca tego roku Tymczasowy Rząd Jedności Narodowej (TRJN), stąd rząd norweski domagał się jak najszybszego przysłania do Oslo przedstawiciela nowej Polski. Decydowały o tym zarówno względy prestiżowe, jak i sprawy gospodarcze. Mianowanie bowiem wspólnego przedstawiciela na Szwecję i Norwegię z siedzibą w Sztokholmie nie odpowiadało Norwegii z uwagi na niedawny, trwający 91 lat (1814-1905) związek unijny ze Szwecją. Dał temu wyraz ambasador norweski w Moskwie Rolf Andvord podczas swojej kilkudniowej wizyty w Warszawie na początku sierpnia $1945 \mathrm{roku}$, w trakcie której organizował miejsce pobytu dla norweskiej placówki i nawiązywał pierwsze kontakty dyplomatyczno-handlowe z Polską (Denkiewicz-Szczepaniak 2012: 23-50). Podczas wizyty w polskim MSZ w dniu 6 sierpnia 1945 roku żalił się, „że do chwili wyjazdu z Moskwy nie otrzymał odpowiedzi na swoją notę o uznaniu TRJN przez Norwegię". Prosił też, aby w Oslo mógł przebywać osobny i stały przedstawiciel Polski i aby znalazł się tam możliwie jak najprędzej, bowiem „rząd norweski przykłada do tego dużą wagę"1.

O sytuacji na terenie Norwegii informuje TRJN osoba, której nazwisko pojawia się na dobre podczas organizowania Polskiej Misji Repatriacyjnej. Jest nim Jerzy Halwic, robotnik Organizacji Todt, który przybył na północ Norwegii w 1942 roku z niemiecką firmą Bodmann u. Hildebrandt z Łodzi - związaną umową z OT - jako jej stały robotnik (OT-Stammarbeiter). W Norwegii natomiast $\mathrm{z}$ uwagi na brak kadry został zatrudniony na stanowisku księgowego tejże firmy. Po zakończeniu wojny, podobnie jak wielu polskich robotników Organizacji Todta, oczekiwał na ewakuację w jednym z kilkunastu obozów odosobnienia dla cywilów. W tym czasie został zwerbowany przez przedstawiciela TRJN w Sztokholmie charge d’affaires

1 Archiwum Ministerstwa Spraw Zagranicznych w Warszawie (AMSZ), Z. 6, W. 76, T. 1091, Notatka pro domo z 6.08.1945 r., k. 1. 
Jerzego Pańskiego do współpracy ze wspomnianym rządem warszawskim ${ }^{2}$. Należy dodać, że Pański był podczas wojny w Szwecji korespondentem agencji prasowej Polpress utworzonej 10 marca 1944 roku w Moskwie przez tamtejszy komunistyczny Związek Patriotów Polskich, a po zakończeniu wojny został mianowany przez TRJN na stanowisko charge d'affaires w trzech krajach skandynawskich - Szwecji, Danii i Norwegii. Napisany odręcznie przez Halwica w sierpniu 1945 roku donos, a więc jeszcze w trakcie jego pobytu w Norwegii, świadczy o jego dobrej orientacji w sprawach norweskich. Z dość dużą dokładnością ocenia bowiem sytuację w tym kraju, wymieniając i charakteryzując osoby związane z rządem londyńskim, w tym polskich oficerów łącznikowych, którzy sprawowali opiekę nad polskimi jeńcami wojennymi i osobami cywilnymi ${ }^{3}$. Dla władz w Warszawie sprawozdanie Halwica było z pewnością impulsem skłaniającym do zajęcia się ogromną rzeszą Polaków w Norwegii, których należało jak najszybciej ewakuować do kraju, co ułatwiał w pewnym stopniu fakt, że z początkiem września Poselstwo w Sztokholmie przejął Adam Ostrowski, poseł z ramienia TRJN. Ostrowski otrzymał niebawem pomoc w obsadzeniu placówek dyplomatycznych w Danii i Finlandii, a w przypadku Norwegii - zgodnie z poleceniem MSZ i w kontakcie z posłem Republiki Jugosławii - uzyskał jedynie zgodę, aby zamieszkały w Oslo honorowy konsul generalny Jugosławii Bjarne Holter-Sørensen załatwiał pilne sprawy obywateli polskich, zaś w sprawach ważniejszych, związanych zwłaszcza z repatriacją, miał zwracać się do Wydziału Konsularnego Poselstwa w Sztokholmie ${ }^{4}$. Potwierdzenie tego znajdujemy w dokumentacji norweskiej, w piśmie odręcznie sporządzonym przez sekretarza norweskiego MSZ (Utenriksdepartementet, UD) Georga Collina $\mathrm{z}$ dnia 18 listopada 1945 roku $^{5}$.

W jednym ze swych raportów do J. Olszewskiego, dyrektora Departamentu Politycznego MSZ, J. Pański pisał o dotyczącej Polaków w Norwegii wizycie w Oslo, na którą został zaproszony przez rząd norweski. Stwierdzał, że rząd norweski powołał konferencję delegatów z obozów polskich, na której obradowano nad repatriacją Polaków. Wyrażono też wotum nieufności wobec oficerów łącznikowych rządu londyńskiego i proszono go o przysłanie oficerów łącznikowych z Polski. Pełny tekst raportu: AMSZ, Z. 6, W. 78, T. 1165, Notatki polityczne [Jerzy Pański, Adam Ostrowski], raport nr 5, k. 20.

$3 \quad$ AMSZ, Z. 6, W. 76, T. 1092, J. Halwic, Sprawozdanie z działalności osób szkodliwych dla Państwa Polskiego na terenie Norwegii.

$4 \quad$ AMSZ, Z. 6, W. 76, T. 1090, Pismo A. Ostrowskiego z 20.11.1945 r. do MSZ, Departament Konsularny w Warszawie, k. 1. Zagadnienie to zostało szerzej przedstawione w artykule: Denkiewicz-Szczepaniak (2018a: 214-216).

5 Riksarkivet (RA), Utenriksdepartementet (UD), 1940-1949, boks 10165, 14.21/91, Polens sendemann i Norge, Notatka G. Collina z 18.11.1945 r. pt. Polens representasjon i Oslo, s. 1-2. 


\section{Objęcie placówki przez Mieczysława Rogalskiego}

Dopiero w połowie lutego 1946 roku zapadły decyzje w polskim MSZ dotyczące kandydatury na Posła TRJN w Norwegii. Dnia 15 lutego dyrektor Protokołu Dyplomatycznego Adam Gubrynowicz powiadomił Biuro Personalne, że Mieczysław Rogalski otrzymał listy uwierzytelniające skierowane do króla Norwegii Haakona VII, podpisane przez Prezydenta KRN Bolesława Bieruta ${ }^{6}$. W dniu 19 lutego Bierut informował na piśmie Rogalskiego - ówczesnego Dyrektora Departamentu Konsularnego MSZ - o mianowaniu go Posłem Nadzwyczajnym i Ministrem Pełnomocnym przy Rządzie Królestwa Norwegii w Oslo ${ }^{7}$. Z prasy norweskiej dowiadujemy się, że Rogalski przyleciał do Oslo wraz z małżonką w sobotę 6 kwietnia samolotem ze Sztokholmu, gdzie przebywał od środy 3 kwietnia ${ }^{8}$. Kim był Rogalski i jakie miał przygotowanie i doświadczenie zawodowe?

Mieczysław Rogalski urodził się 23 maja 1889 roku w Warszawie. Gimnazjum ukończył w stolicy, zaś studia wyższe odbył najpierw na Wydziale Prawa w Liège w Belgii, a następnie na Wydziale Filozoficznym Uniwersytetu Jagiellońskiego. Ukończył również Szkołę Nauk Politycznych - Wydział Dyplomatyczno-Konsularny w Warszawie. Od 1916 roku był nauczycielem w Lublinie, później asystentem na nowo powołanym Uniwersytecie Lubelskim. W latach 1919-1928 był zatrudniony w MSZ - najpierw na stanowisku referendarza, później w Departamencie Politycznym, a na koniec w Wydziale Traktatowo-Naukowym jako kierownik referatu umów zbiorowych. W latach 1928-1930 pełnił obowiązki sekretarza Poselstwa RP w Bukareszcie, po czym wrócił do Departamentu Konsularnego MSZ, gdzie pracował do 1932 roku. Od 1932 do 1939 roku sprawował urząd konsula na terenie Prus Wschodnich, najpierw przez rok w Olsztynie jako wicekonsul I klasy, a w latach 1932-1936 jako konsul RP w Kwidzynie. Od 1936 roku do wybuchu wojny był konsulem generalnym w Ełku. We wrześniu 1939 roku udało mu się przedrzeć do kraju i ukryć w Lublinie, gdzie przez sześć lat pracował jako zwykły robotnik, wykonując zawód malarza. W tym czasie był kilkakrotnie aresztowany i więziony przez Niemców. Od lipca do sierpnia 1944 roku zaangażował się w działalność na rzecz PKWN, zajmując się organizowaniem oświaty. Od 24 sierpnia 1944 roku przeszedł do resortu spraw zagranicz-

\footnotetext{
6 AMSZ, Z. 16 Protokół Dyplomatyczny, W. 36 Norwegia, T. 621, pismo z 15.02.1946 r. do Biura Personalnego, k. 5; w załączniku kopia listu uwierzytelniającego, k. 6-7.

AMSZ, Z. 16 Protokół Dyplomatyczny, W. 36 Norwegia, T. 621, pismo z 15.02.1946 r. do Biura Personalnego, k. 8.

8 RA, UD 1940-1949, boks 10165, 14.21/91 Polens sendemann i Norge, Artykuł z Aftenposten z 8.04.1946 r. pt. Ny polsk minister i Norge. Artykuł zawiera też na końcu adnotację: „I sekretarz poselstwa Andrzej Zalewski przybył do Oslo parę dni temu statkiem, zaś pozostały personel poselstwa - II sekretarz, attaché prasowy i kancelista są oczekiwani w najbliższym czasie".
} 
nych PKWN, pełniąc funkcję zastępcy kierownika tegoż resortu. Współpracował z premierem Edwardem Osóbką-Morawskim i członkiem Biura Politycznego Komitetu Centralnego Polskiej Partii Robotniczej (KC PPR) Jakubem Bermanem. We wrześniu 1944 roku reprezentował rząd w sprawach ewakuacji, a od grudnia tego roku był posłem Krajowej Rady Narodowej (KRN) z ramienia prokomunistycznego Stronnictwa Demokratycznego, zwanego Stronnictwem Polskiej Demokracji (SPD), które powstało 4 lipca 1943 roku wskutek rozłamu w dotychczasowym Stronnictwie Demokratycznym ${ }^{9}$. W prokomunistycznym Stronnictwie Demokratycznym był członkiem prezydium. Z dniem 1 stycznia 1945 roku został mianowany dyrektorem Departamentu Konsularnego MSZ. Aktywnie angażował się w pracę polityczną na rzecz PKWN i wielu towarzystw, takich jak Towarzystwo Przyjaźni Polsko-Radzieckiej i Towarzystwo Przyjaźni Polsko-Francuskiej. Należy też nadmienić, że w latach młodości działał do 1918 roku w PPS-Lewica, a od 1918 roku przez dziesięć lat w PSL-Wyzwolenie. Od 1928 roku pozostawał poza jakąkolwiek przynależnością partyjną aż do sierpnia 1944 roku, kiedy zaangażował się w działalność konspiracyjną SPD jako komendant Okręgu Lubelskiego OWO (Obozu Wyzwolenia Ojczyzny). Żonaty z Ludwiką Klaudią z Potockich, urodzoną 21 grudnia 1916 roku. Miał dwójkę dzieci z pierwszego małżeństwa, które zginęły w Warszawie podczas powstania ${ }^{10}$. Zmarł 15 maja 1952 roku w Iwoniczu-Zdroju.

Życiorys Rogalskiego wskazuje na to, że był doświadczonym dyplomatą wieloletnim urzędnikiem administracji MSZ, znającym równocześnie rzeczywistość powojenną. Posługiwał się przy tym swobodnie powszechnie używanym w dyplomacji językiem francuskim, także niemieckim, rosyjskim i rumuńskim. Był zatem dobrze przygotowany do pracy w dyplomacji międzynarodowej, choć stanowisko posła sprawował po raz pierwszy. Po przybyciu do Oslo (6 kwietnia) już 10 kwietnia złożył wizytę $\mathrm{w}$ norweskim UD, rozmawiał $\mathrm{z}$ ministrem spraw zagranicznych Halvardem Lange i jego zastępcą Perem Prebensenem, wręczając ministrowi kopię listów uwierzytelniających. Oryginał listów złożył na ręce króla Haakona VII dopiero po świętach wielkanocnych w dniu 27 kwietnia. Złożył też wizytę w korpusie dyplomatycznym w Oslo, gdzie spotkał dawnych kolegów, między innymi sekretarza Poselstwa RP w Bukareszcie czy kolegę ze studiów w Belgii. Został też przyjęty przez dziekana korpusu - ambasadora ZSRS Nikołaja Kuzniecowa. W liście informował również, że na Islandię wybierze się dopiero około 10 czerwca, podobnie jak miało to uczynić wielu posłów będących reprezentantami równocześnie na Norwegię i Islandię. Wówczas zamierzał złożyć listy uwierzytelniające i wziąć udział w uroczystościach rocznicowych przypadających na

9 Szerzej: Encyklopedia Powszechna (2009: 52).

10 AMSZ, Nabytek 24.97, W. 17, Karta Personalna M. Rogalskiego z dnia 17.01.1945 r. i życiorys, k. 3-7. 
17 czerwca, czyli w drugą rocznicę proklamowania republiki Islandii ${ }^{11}$. W oddzielnym liście do szefa departamentu politycznego MSZ Józefa Olszewskiego Rogalski pisał o sytuacji, jaką zastał w Oslo, podkreślając zwłaszcza „negatywne wpływy przedstawicieli polskiego rządu emigracyjnego w Oslo na sprawę repatriacji Polaków z Norwegii” oraz to, że przyczyną złej kampanii w prasie na temat Polski jest między innymi długotrwała nieobecność przedstawiciela Polski w Norwegii. Pisał też o trudnych warunkach lokalowych poselstwa mieszczącego się w dwóch pokojach w Grand Hotelu w Oslo, z których jeden z alkową zajmował wraz z małżonką, a sąsiedni mały pokój przeznaczył na gabinet biurowy. Poseł narzekał na brak środków na opłacenie tych pomieszczeń, bowiem dziennie był to koszt minimum 60 koron, dlatego też personel Poselstwa został rozmieszczony w tańszych, trzeciorzędnych pensjonatach. Pisał też, że ma zbyt skromny personel, mniejszy, niż ustalił to przed swoim wyjazdem, bowiem zamiast planowanych sześciu osób były tylko dwie: II sekretarz Andrzej Zalewski i naczelnik kancelarii Kazimierz Święcicki. Na koniec podkreślał potrzebę zwiększenia budżetu dla placówki i wpłynięcia na Biuro Personalne, aby zwiększyć choć trochę liczbę personelu, a zwłaszcza zatrudnić attaché handlowego ${ }^{12}$. Taki stan trwał jednak niedługo, bowiem na początku czerwca Poselstwu udało się wydzierżawić dwupiętrową willę przy Olav Kyrres plass 1. Po przeprowadzeniu odpowiednich przygotowań Poselstwo przeniosło się do willi, gdzie rozpoczęło swe urzędowanie już 12 czerwca $1946 \mathrm{roku}^{13}$. Warto w tym miejscu dodać, że polska placówka mieści się tam do dnia dzisiejszego.

\section{Sprawa repatriacji Polaków z Norwegii - sytuacja w 1946 roku}

Lato i jesień 1946 roku przebiegały pod znakiem baczniejszego przyglądania się władz norweskich Polakom pozostającym nadal w Norwegii, ale bardziej już pod kątem możliwości ich zatrudnienia. W maju 1946 roku ze wspomnianych wyżej 17 287 Polaków nadal pozostawało w Norwegii około 1100 polskich obywateli. Osoby te rozlokowano w trzech obozach repatriacyjnych znajdujących się w południowo-wschodniej Norwegii (Mysen, Moss i Ystehede). Władze norweskie chciały jednak, aby możliwie jak najwięcej z nich wróciło do kraju, tym bardziej, że istniało już Poselstwo RP w Oslo, które powinno zająć się tą sprawą. Tymczasem Poselstwo nie wykazywało zainteresowania tą kwestią, o czym świadczy pierwszy skierowany do MSZ raport Rogalskiego. Poza wzmianką o trzech polskich obozach na terenie Norwegii,

11 AMSZ., Z. 6, W. 76, T. 1094 - Objęcie placówki przez M. Rogalskiego, list M. Rogalskiego do ministra J. Olszewskiego z 10.10.1946 r., k. 1-2.

12 AMSZ, Z. 6, W. 76, T. 1096, list M. Rogalskiego do J. Olszewskiego z 10.04.1946 r.

13 AMSZ, Z. 6, W. 76, T. 1095, Sprawozdanie W. Przesmyckiego z 15.06.1946 r. z podróży służbowej do Oslo i Kopenhagi, k. 2. 
w których - jak stwierdził - „znajduje się element całkowicie politycznie negatywny, złożony przeważnie z szumowin, nawet mętów kryminalnych, ludzi młodych, zdemoralizowanych przez wojnę, rozpróżniaczonych, podatnych do spełnienia roli płatnych agentów", nie podawał żadnych konkretów, nie mówiąc o bliższym nawiązaniu kontaktów z Polakami ${ }^{14}$. Bardziej natomiast interesowało go pozbawienie wpływów przedstawicieli polskiego rządu emigracyjnego z Londynu w tych obozach niż dalsza akcja repatriacyjna. Chodziło tu głównie o oficerów łącznikowych polskiego rządu emigracyjnego na czele $\mathrm{z}$ kpt. Zbigniewem Pierścianowskim, a także o attaché ds. wojskowych płk. Tadeusza Tokarza. Raport Rogalskiego wypełniony był jedynie krytyką owych przedstawicieli i ich działań w polskich obozach. Poseł Rogalski wymieniał też inż. Bolesława Witowskiego - przedwojennego sekretarza Poselstwa RP w Oslo, a po wojnie prezesa Związku Polaków w Norwegii, a także kapitana marynarki handlowej Romana Budkę. Obaj panowie byli najbardziej związani ze wspomnianymi oficerami łącznikowymi rządu emigracyjnego. Rogalski stwierdzał, zgodnie z rzeczywistością, że ww. oficerowie łącznikowi kierowali Związkiem Polaków w Norwegii, którego siedziba znajdowała się w Oslo na ulicy Munkedamsveien 53. Związek ten poza udzielaniem Polakom bieżącej pomocy wydawał też pismo Wiadomości Polskie w Norwegii. Rogalski w swoich dociekaniach dotyczących organizowania się Polonii w Norwegii popierającej polski rząd emigracyjny w Londynie stwierdził też, zgodnie z realiami, że Tokarz był oficjalnym przedstawicielem owego rządu w Londynie. Nadto dodawał, że jest to osoba, z którą polskie obozy repatriacyjne na terenie Norwegii mogły porozumiewać się we wszystkich sprawach i od której mogły odbierać instrukcje. Naturalnie, z powodów czysto politycznych Rogalski oceniał działalność Tokarza jako szkodliwą i tak uzasadniał swoje aide-mémoire skierowane do norweskiego UD, z czym ww. sekretarz generalny UD Per Prebensen musiał się zgodzić, bowiem Norwegia, jak podano wcześniej, już 6 lipca 1945 roku uznała TRJN ${ }^{15}$. Rogalski wspomniał o jeszcze jednej istotnej sprawie, która stanowiła rodzaj presji zarówno dla Poselstwa RP w Oslo, jak i władz norweskich. Była to informacja o tym, że Rogalskiego odwiedził attaché wojskowy ambasady sowieckiej, niejaki płk Petrenko, który miał stwierdzić, że prawdopodobnie Polacy z obozu w Mysen, którym pomagał Tokarz, mieli być szkoleni jako skoczkowie spadochronowi $\mathrm{w}$ celu zasilenia band polskich walczących z nowymi władzami w Polsce ${ }^{16}$. Podobnie więc jak w przypadku Patka, los płk Tokarza angażującego się w pomoc Polakom pozostającym w Norwegii był przesądzony z powodów czysto politycznych, w których

14 AMSZ, Z. 6, W. 76, T. 1096, Norwegia 242, Raporty i notatki polityczne Poselstwa RP w Oslo, Raport o sytuacji politycznej w Norwegii M. Rogalskiego z 16.04.1946 r. do J. Olszewskiego, k. 2. 15 AMSZ, Z. 6, W. 76, T. 1096, Norwegia 242, Raporty i notatki polityczne Poselstwa RP w Oslo, Raport polityczny M. Rogalskiego z 9.11.1946 r., k. 30.

16 AMSZ, Z. 6, W. 76, T. 1096, Norwegia 242, Raporty i notatki polityczne Poselstwa RP w Oslo, Raport polityczny M. Rogalskiego z 30.08.1946 r., k. 24. 
specjalną rolę odgrywała presja ambasady sowieckiej w Oslo. Była to więc zasadnicza przyczyna nadmiernej aktywności Rogalskiego w kwestii jak najszybszego wyeliminowania „wszelkich elementów londyńskich” z terytorium Norwegii. Według Rogalskiego jedyną pozytywną jednostką był przebywający od siedmiu lat w Norwegii astrofizyk prof. Jeremi Wasiutyński, który - jak podkreślał Rogalski - był znawcą spraw politycznych, społecznych i ekonomicznych Norwegii, stąd proponował, aby „przyjąć go na fundusz dyspozycyjny Poselstwa i wciągnąć do bliższej współpracy, na co chętnie pójdzie, bo ma nader skromne warunki” ${ }^{17}$. W kolejnym raporcie Rogalski chwalił się już pierwszym kontaktem z Wasiutyńskim, który miał go poinformować, że chciał się z nim zobaczyć wspomniany już prezes Związku Polaków w Norwegii inż. Witowski. W kwestii kontaktu z Polakami w obozach Rogalski stwierdzał jedynie, że zamierzał się tam wybrać w niedalekiej przyszłości, a także planował udać się do siedziby Związku Polaków, aby „wytworzyć koło siebie choćby skromną grupkę tutejszej Polonii” i zapewne w dalszej kolejności „zorganizować związek patriotów, do którego można by stopniowo przeciaggać ludzi”"18. I to w zasadzie wszystko, bo tak naprawdę Rogalski nigdy nie wybrał się osobiście do polskich obozów, wysłał natomiast w czerwcu do obozów w Mysen i Moss Zalewskiego, sekretarza Poselstwa. Tenże poinformował Rogalskiego, że znajdujący się tam Polacy są otumanieni wrogą propagandą, a przysłana przez rząd warszawski Polska Misja Repatriacyjna (PMR) nie wywiązała się ze swego zadania, bowiem tylko 150 osób zgłosiło się do repatriacji w drugiej połowie czerwca 1946 roku, za co obwiniano szefa PMR na terenie Norwegii por. Józefa Jodłowskiego, który miał - w opinii Zalewskiego - zrazić znajdujących się w obozach Polaków do powrotu do Polski. W raporcie z 16 czerwca 1946 roku Rogalski stwierdzał też, że obozy zaopatrywane były w prasę i materiały propagandowe, sygnalizując równocześnie władzom potrzebę dostarczenia portretów członków polskiego TRJN, tak aby można było umieścić je w barakach obozowych $^{19}$. Z kolei trzeci z obozów, Ystehede, w którym znajdowały się głównie małżeństwa norwesko-polskie, był wizytowany przez Zalewskiego dopiero 26 września 1946 roku. Zalewski pisał w raporcie o spotkaniu z około 100 osobami, które w tym czasie znajdowały się akurat w obozie, natomiast pozostali (ok. 260 osób) pracowali poza obozem, zatrudnieni głównie w okolicznych norweskich gospodarstwach. Zalewski dostrzegał tu rzecz zasadniczą i zgodną z rzeczywistością, a mianowicie fakt, że Polacy z uwagi na swe małżeństwa z Norweżkami i dzieci zrodzone z tych związków znajdowali duże wsparcie u miejscowych rodzin. Stąd podkreślał, że niedawna

17 AMSZ, Z. 6, W. 76, T. 1096, Norwegia 242, Raporty i notatki polityczne Poselstwa RP w Oslo, Raport M. Rogalskiego o sytuacji politycznej w Norwegii z 16.04.1946, k. 3-5.

18 AMSZ, Z. 6, W. 76, T. 1096, Norwegia 242, Raporty i notatki polityczne Poselstwa RP w Oslo, Raport polityczny M. Rogalskiego z 13.05.1946 r., k. 10.

19 AMSZ, Z. 6, W. 76, T. 1096, Norwegia 242, Raporty i notatki polityczne Poselstwa RP w Oslo, Raport M. Rogalskiego z 16.06.1946 r., k. 18-19. 
wizyta w obozie płk. Tokarza, który namawiał Polaków do bojkotowania powrotu do kraju, przyniosła efekty. Jest to chyba pewnego rodzaju usprawiedliwienie dla marnych rezultatów, jakie on sam uzyskał po wizycie w obozie - mimo że opowiadał o aktualnych sukcesach Polski, do powrotu zgłosiło się zaledwie parę samotnych osób $^{20}$. Z dokumentacji norweskiej wynika także, że o niepowodzeniu letniej repatriacji w 1946 roku grupy około 250-300 Polaków zdecydowała wizyta płk. Tokarza w obozach, a w największym obozie Mysen także przyjazd prezesa Związku Polaków w Norwegii inż. Witowskiego. W rezultacie, jak pisze szef norweskiego Biura Repatriacyjnego Dagfinn Juel, liczba chętnych do wyjazdu w obozie Mysen spadła do 75 osób. W sumie ze wszystkich trzech obozów zgłosiło się do wyjazdu zaledwie około 100 osób. Dołączono do nich 11 Polaków, którzy za wykroczenia o charakterze karnym zostali usunięci z obozu karnego Grefsrud i dołączeni przymusowo do repatriantów. W sumie w dniu 22 czerwca 1946 roku na niemieckim statku „Erna” odpłynęło z Moss do kraju zaledwie 110 Polaków ${ }^{21}$.

\section{Sukcesy dyplomatyczne posła Rogalskiego}

Pierwszą i niewątpliwie najważniejszą wizytą Rogalskiego była audiencja u króla Haakona VII w dniu 27 kwietnia 1946 roku, podczas której złożył oryginały listów uwierzytelniających. Rogalski pisał, że król przyjął go „bardzo serdecznie i po przyjacielsku. Pomimo 73 lat trzyma się dobrze, wysoki, chudy, ale o pogodnym wyrazie twarzy. Rozmowa toczyła się na wszelkie tematy i trwała trzy kwadranse. Król przeważnie mówił o przeżyciach wojennych, o powrocie swym do kraju, o ruchu oporu, o Hitlerze. W sprawach Polski interesował się zniszczeniami kraju i Warszawy”. Trzy dni później, 30 kwietnia, Rogalski został przyjęty przez księcia Olava, który - jak zauważył - „interesował się w szerszym zakresie sprawami ekonomicznymi Polski”. Rozmowa odbyła się w prywatnym gabinecie księcia w cztery oczy. Rogalski szybko też nawiązał kontakt z Langem, ministrem spraw zagranicznych Norwegii. Poza wspomnianą wcześniej wizytą tuż po przyjeździe do Norwegii przeprowadził z nim w krótkim czasie dwie rozmowy - jedną w sprawie uroczystości w Narviku i drugą dotyczącą stosunków gospodarczych z Polską, w tym głównie kwestii dostaw polskiego węgla do Norwegii ${ }^{22}$. W następnych miesiącach utrzymywał z nim dość częste kontakty. W dniu 28 września informował

\footnotetext{
20 AMSZ, Z. 6, W. 76, T. 1098 Norwegia 531, Opieka nad deportowanymi i jeńcami (sytuacja w obozach polskich), Raport z wizytacji obozu polskiego w Ystehede w dn. 26.09.1946 r., załącznik do pisma M. Rogalskiego z 28.09.1946 r. do J. Olszewskiego, k. 5-7.

${ }_{21}$ RA, Sosialdepartementet, Flyktnings- og Fangedirektoratet (SD FFD), Sentral arkiv, E.0082, 9.14. Dp., Transport spm., Dagfinn Juel, Fortrolig notat av 26. juni 1946: Repatriering av polakker. 22 AMSZ, Z. 6, W. 76, T. 1096, Raport polityczny M. Rogalskiego z 13.05.1946 r., k. 8.
} 
już o piątej wizycie u Langego, podczas której minister poinformował go, że strona norweska jest gotowa do negocjacji handlowych z Polską, aby zawrzeć jak najszybciej umowę handlową ${ }^{23}$. W następnych miesiącach ten bezpośredni kontakt stał się coraz bardziej sporadyczny, bowiem przyjęcia dla szefów misji odwołano na czas nieograniczony, co zdaniem Rogalskiego było spowodowane wynikającą z przeżyć obozowych Langego depresją i trudnościami z utrzymaniem równowagi psychicznej. Te sensacyjne informacje utrzymywano w tajemnicy, ale - jak widać Rogalski obracał się swobodnie w świecie dyplomacji, skoro o tym wiedział. Sam zresztą podczas wizyty u Langego w lutym 1947 roku zauważył pewne symptomy jego choroby ${ }^{24}$. Kolejna wizyta u Langego miała miejsce dopiero 22 października 1947 roku, kiedy Lange wrócił z Ameryki i wznowił stałe przyjęcia szefów placówek dyplomatycznych w Oslo. Rogalski pisał, że Lange przyjął go jak zawsze bardzo serdecznie i mówił mu, że oczekuje delegacji handlowej z Polski dla przeprowadzenia negocjacji handlowych. Chodziło o zwiększenie importu polskiego węgla. Rogalski dodał przy okazji, że z Langem łączą go dobre koleżeńskie stosunki, bowiem obaj studiowali w Liège - Lange w kolegium, a Rogalski na tamtejszym uniwersytecie. Podkreślał też, że zmiana na stanowisku sekretarza generalnego norweskiego UD (po Prebensenie został nim Andvord) wpłynęła korzystnie na relacje między polską placówką dyplomatyczną w Oslo a władzami norweskimi, nie mówiąc już o tym, że Andvord ułatwił usunięcie przedstawicieli polskiego rządu emigracyjnego z Norwegii i zdziałał w tej mierze więcej, jak stwierdził Rogalski, niż jego poprzednik ${ }^{25}$.

Generalnie pozycja Rogalskiego w kontaktach z rządem norweskim wzrastała, a także była dość mocna w samym korpusie dyplomatycznym. Już w pierwszych dniach, jak twierdził, znalazł oparcie w jugosłowiańskim pośle Jugosławii dr. Ivanie Ribarze, z którym znał się od czasu swego sekretarzowania w Poselstwie RP w Bukareszcie w 1929 roku. Spotkał też w Oslo belgijskiego posła J. Vierseta, swego dawnego kolegę ze studiów uniwersyteckich w Belgii. Podkreślał też dobre relacje z posłem Wielkiej Brytanii Laurence’em Collierem, który był dziekanem korpusu dyplomatycznego w Oslo, co nie było bez znaczenia, tym bardziej, że Collier cieszył się dużymi wpływami na tamtejszym dworze królewskim. Drugie miejsce w korpusie dyplomatycznym zajmował ambasador francuski Jacques-François Blondel, który podobnie jak Rogalski rozpoczynał karierę dyplomatyczną w Bukareszcie, a trzecie miejsce - ambasador ZSRS Nikołaj Kuzniecow, radca ambasady

\footnotetext{
23 AMSZ, Z. 6, W. 76, T. 1096, Norwegia 242, Raporty i notatki polityczne Poselstwa RP w Oslo, pismo poufne M. Rogalskiego z 28.09.1946 r. do J. Olszewskiego, k. 29.

${ }^{24}$ AMSZ, Z. 6, W. 76, T. 1102, Charakterystyka partii politycznych, pismo poufne M. Rogalskiego z 25.02.1947 r. do J. Olszewskiego, k. 2.

25 AMSZ, Z. 6, W. 76, T. 1100, Norwegia 08, Sprawozdania z rozmów 1947-1948, pismo poufne M. Rogalskiego do J. Olszewskiego z 23.10.1947 r., k. 4-5.
} 
sowieckiej w Londynie, dobrze znający króla Haakona VII. Znajomość z czasów studenckich $\mathrm{z}$ Viertesem pozwoliła Rogalskiemu na wejście w bliższy kontakt z posłem holenderskim Georgem Paulem Ludenem. Miało to tym większe znaczenie, że Zofia Brill, z domu Majcherek, przewodnicząca Sekcji Polskiej Czerwonego Krzyża w Oslo, Polka, zamężna z obywatelem holenderskim, który był dyrektorem filii Philipsa w Oslo, miała wpływ na prolondyńską polską emigrację. Jak podkreślał Rogalski, Brill zmieniła nastawienie wobec polskiej placówki dyplomatycznej, co przełożyło się na to, że większość zarządu Czerwonego Krzyża nawiązała z placówką kontakt, co naturalnie Rogalski zamierzał wykorzystać, przy równoczesnej pilnej obserwacji tych ludzi ${ }^{26}$.

Wszystkie te informacje wskazują na to, że Rogalski szybko odnalazł się w świecie dyplomacji. Trafnie dokonał charakterystyki systemu politycznego w Norwegii. Dobrze ocenił pozycję i rolę rządzącej w Norwegii Partii Robotniczej (Det norske Arbeiderpartiet, DNA) i jej głównych przywódców. Nie przecenił przy tym znaczenia Partii Komunistycznej (Norges Kommunistiske Parti, NKP), podkreślając, że to Partia Robotnicza ma decydujący wpływ na dobre relacje między Polską a Norwegią. Podkreślał też swoje osobiste kontakty z wieloma politykami i członkami rządu oraz parlamentu norweskiego. Nadmieniał przy tym, że znał wszystkich ministrów i wybitne osobistości dworu królewskiego. Nawiązał też kontakty ze światem naukowym, między innymi z rektorem Uniwersytetu w Oslo Otto Lousem Mohrem czy profesorem Johanem Schreinerem ${ }^{27}$.

Najbardziej cennymi i wielokrotnie wertowanymi przez polski MSZ - biorąc pod uwagę liczbę odręcznych adnotacji sporządzonych przez urzędników MSZ na marginesach raportów - są przygotowane przez Rogalskiego raporty oceniające zmiany w polityce zagranicznej Norwegii zachodzące w 1947 roku. Chodzi tu między innymi o raport poufny z 24 lipca tegoż roku do Olszewskiego, w którym Rogalski przedstawił wzrost wpływów amerykańskich w Norwegii. Pisał w nim o znaczącym zwiększeniu amerykańskiego eksportu do Norwegii, który jego zdaniem $\mathrm{w}$ porównaniu $\mathrm{z}$ latami przedwojennymi podwoił się, a w niektórych dziedzinach nawet potroił ${ }^{28}$. Główne zasługi w tej kwestii przypisuje Charlesowi Bayowi, ambasadorowi USA w Norwegii w latach 1946-1953. Bay posiadał korzenie norweskie, jego rodzice byli emigrantami z Norwegii, a matka wywodziła się z położonego daleko na północy Hammerfest ${ }^{29}$. Do czasu objęcia placówki w Oslo był

26 AMSZ, Z. 6, W. 76, T. 1096, Norwegia 242, Raporty i notatki polityczne Poselstwa RP w Oslo, Raport polityczny M. Rogalskiego z 29.06.1946 r., k. 20-22.

${ }_{27}$ AMSZ, Z. 6, W. 76, T. 1102, raport poufny M. Rogalskiego do J. Olszewskiego z 24.06.1947 r., k. 3-4.

28 AMSZ, Z. 6, Norwegia 242, W. 76, T. 1103, pismo poufne M. Rogalskiego do J. Olszewskiego z 24.07.1947 r., k. 1-13.

29 Charles Ulrick Bay (1888-1955) - amerykański finansista i dyplomata, syn emigrantów norweskich. Politycznie popierał demokratów; w latach 1946-1953 ambasador USA w Oslo; 
kupcem i przemysłowcem, stąd problemy ekonomiczne, jak podkreśla Rogalski, miały dla niego największe znaczenie. Ale niewątpliwie najważniejszą informacją podawaną przez Rogalskiego była ta dotycząca opracowanego przez Baya specjalnego planu ekonomicznej ofensywy Ameryki na kraje skandynawskie. Plan ten zakładał ścisłą współpracę między USA a Norwegią, Danią i Szwecją, zwłaszcza w sprawach przemysłu metalurgicznego. Według tego planu fabryki norweskie produkujące części do maszyn miałyby rozszerzyć swą produkcję na USA. Jeśliby plan ten się powiódł, Bay proponował włączyć do niego Szwecję i Danię. W tym celu mieli przybyć do Norwegii przedstawiciele fabryk amerykańskich z konkretnymi zamówieniami na części do ich maszyn. Na początek byłaby to masowa produkcja części do samochodów amerykańskich, później rozszerzona na inne branże metalurgiczne. Na koniec Rogalski ostrzegał rząd polski, że plan Baya groził ograniczeniem stosunków ekonomicznych z Polską. Na to nakładała się amerykańska propozycja pożyczki dla Norwegii rzędu 100 milionów dolarów. Najbardziej trafne było ostatnie zdanie Rogalskiego: „Na szczęście Norwegowie są dość ostrożni i niewyrywni, doceniają swoją obecną pozycję polityczną i względy bezpieczeństwa przy ewentualnym konflikcie" ${ }^{\prime 3}$. Naturalnie chodziło tu o trudne relacje pomiędzy USA a ZSRS, a w przypadku Norwegii szczególnie o liczącą ponad $90 \mathrm{~km}$ wspólną granicę z ZSRS, pilnie strzeżoną przez sowiecką straż graniczną.

W dokumentacji MSZ znajdujemy jeszcze jedno ostrzeżenie Rogalskiego tym razem o charakterze politycznym, związane z wizytą w Polsce Haakona Lie, znanego polityka, sekretarza norweskiej Partii Robotniczej w latach 1945-1969. Lie przybył do Polski w grudniu 1946 roku na zaproszenie premiera Edwarda Osóbki-Morawskiego i sekretarza generalnego PPS Józefa Cyrankiewicza. Rogalski w tajnym piśmie do MSZ z 28 grudnia 1946 roku podkreślał, że Lie jest osobistością usposobioną do Polski bardzo krytycznie, ma wrogi stosunek do Związku Sowieckiego, a w Polsce chce dopatrzeć się tylko złych stron dokonanych przemian politycznych. Podkreślał też, że reprezentuje on najbardziej prawicowy odłam norweskiej Partii Robotniczej, dodając równocześnie, że ani premier Einar Gerhardsen, ani minister spraw zagranicznych Halvard Lange nie mogli udać się na wspomniane zaproszenie PPS do Polski ${ }^{31}$.

razem z żoną przeznaczył spore kwoty na cele humanitarne, badania medyczne w Norwegii, studia Norwegów w USA. Był pierwszym Amerykaninem udekorowanym Orderem Królewskim Świętego Olafa; szerzej: Jahr (2013).

30 AMSZ, Z. 6, W. 76, T. 1103, Norwegia 242, pismo poufne M. Rogalskiego do J. Olszewskiego z 24.07.1947 r., k. 13-14.

31 AMSZ, Z. 6, W. 76, T. 1102, Norwegia 242, pismo poufne M. Rogalskiego z 28.12.1946 r. do J. Olszewskiego, k. 1. 


\section{Uroczystości w Narviku}

\section{oraz sprawa wzajemnej wymiany odznaczeń i orderów}

W dniu 28 maja 1946 roku norweskie Ministerstwo Obrony (Forsvarsdepartementet, FD) zorganizowało pierwsze od zakończenia wojny uroczystości o charakterze wojskowym związane ze zwycięstwem pod Narvikiem. Do udziału w nich zostali zaproszeni przedstawiciele czterech państw sprzymierzonych - Francji, Anglii, Polski i Norwegii, których wojska brały udział w walkach o Narvik. Poseł Rogalski stwierdzał w raporcie, że z uwagi na swój niedawny przyjazd do Oslo nie był przygotowany do zgłoszenia przedstawicieli wojska polskiego, ale zachęcony osobistym zaproszeniem Langego, a nadto uzyskawszy zezwolenie MSZ, zgłosił jedynie swój udział wraz z małżonką i sekretarzem poselstwa Zalewskim. To swoiste zrządzenie losu pomogło mu w realizacji zaleceń TRJN, by zapobiec uczestnictwu w tych uroczystościach, jak pisał, „niepożądanych i samozwańczych przedstawicieli rządu emigracyjnego", nie mówiąc o tym, że mógł reprezentować Polskę wraz ze znanymi mu ambasadorami Anglii i Francji ${ }^{32}$. W dalszej części raportu opisywał udział licznych delegacji francuskich i brytyjskich, które oprócz przedstawicieli dyplomatycznych miały w swym składzie generałów i admirałów, dowódców sił francuskich i brytyjskich z walk o Narvik. Delegacje te przybyły samolotami i na pancernikach, podczas gdy on z małżonką i sekretarzem Zalewskim odbyli pociągiem długą, trwającą 40 godzin podróż. Podkreślał też, że delegację polską powitano z honorami i zadbano o jej godną prezentację w trakcie uroczystości ${ }^{33}$. Jak z powyższego wynika, Rogalski potraktował udział polskiej delegacji zgodnie z wymogami TRJN, nie dopuszczając do uroczystości przedstawicieli polskiego rządu emigracyjnego.

Kolejny problem, który wiązał się z uroczystościami narwickimi, stanowiła sprawa wymiany odznaczeń i orderów między Polską a Norwegią. Rogalski, idąc za przykładem Francuzów, którzy już to uczynili, proponował w piśmie do Olszewskiego, aby w dniu 22 lipca udekorować szereg osób wojskowych i cywilnych z Norwegii, podając 100 różnego rodzaju odznaczeń, w tym 4 złote i 6 srebrnych krzyży Virtuti Militari, 40 Krzyży Walecznych dla żołnierzy i oficerów, 10 Krzyży Polonia Restituta różnych klas oraz 40 Krzyży Zasługi. Stwierdzał też, że pożądane byłoby przedstawienie do odznaczenia wszystkich tych żołnierzy i oficerów polskich, którzy brali udział w walkach o Narvik, a znajdują się obecnie w kraju, przy jednoczesnym wykluczeniu zaś tych, którzy odmówili powrotu do Polski. Przewidywał jednak, że liczba znajdujących się w kraju bohaterów spod Narviku będzie zbyt mała, stąd proponował, by do odznaczenia przewidzieć również

32 AMSZ, Z. 6, W. 76, T. 1102, Norwegia 242, Raporty i notatki polityczne Poselstwa RP w Oslo, raport polityczny M. Rogalskiego z 1.06.1946 r., k. 12.

33 AMSZ, Z. 6, W. 76, T. 1102, Norwegia 242, Raporty i notatki polityczne Poselstwa RP w Oslo, raport polityczny M. Rogalskiego z 1.06.1946 r., k. 12-17. 
wszystkich poległych pod Narvikiem, choć tak naprawdę nie wiedział, ilu ich było, skoro stwierdzał, że listę poległych Polaków obiecał mu przygotować prezes norweskiego Czerwonego Krzyża. Rogalskiemu chodziło więc bardziej o odniesienie sukcesu propagandowego i zaistnienie Polski w dyplomacji, zaś samo przyznanie odznaczeń uważał za stosowne, bo Norwegowie - jak stwierdzał - „cenią sobie wszelkie medale honorowe i odznaczenia”. W związku z tym prosił o jak najszybszą odpowiedź MSZ na swoją propozycję, tak aby mógł wysłać listę Norwegów proponowanych do odznaczeń ${ }^{34}$.

Mniej więcej w tym samym czasie z inicjatywą po stronie norweskiej wystąpił poseł Królestwa Norwegii w Warszawie Alfred Danielsen, kierując do UD pismo w kwestii odznaczeń dla polskich bohaterów spod Narviku ${ }^{35}$. UD zwróciło się w tej sprawie do FD, które pismem z 21 września 1946 roku zaproponowało UD, aby przyznać odznaczenia Krzyżem Wolności Króla Haakona VII (Haakon VIIs Frihetskors) dwóm polskim oficerom: gen. Stanisławowi Sosabowskiemu - szefowi polskiej brygady spadochronowej i płk. Tadeuszowi Tokarzowi ${ }^{36}$. I to właśnie pismo, jak na ironię losu, wystosowane zostało w tym samym czasie, kiedy UD zmuszone było do usunięcia Tokarza z Norwegii (na wniosek Rogalskiego) za jego rzekomo wrogą działalność wśród Polaków znajdujących się w tym kraju, która miała być skierowana przeciwko rządowi warszawskiemu. Stąd też już 23 września Georg Collin z UD ze względów czysto politycznych zamieścił na wspomnianym wniosku o odznaczenia dla obu polskich oficerów adnotację, że Tokarz zostanie przypuszczalnie wydalony z Norwegii. Podawał równocześnie w wątpliwość przyznanie w ogóle tych odznaczeń obu polskim oficerom ${ }^{37}$. Należy tu podkreślić, że tę wewnętrzną inicjatywę władz norweskich zduszono w zarodku, bowiem nie została ona opublikowana. Należy przy tym dodać, że Norwegowie chcieli odznaczyć osoby pomagające im w wyszkoleniu nie tylko kompanii spadochronowej, ale też innych jednostek, które weszły w skład Brygady Norweskiej liczącej ogółem 2527 żołnierzy. Warto też nadmienić, że norweski obóz wojskowy znajdował się w Dumfries w Szkocji, niedaleko miejsca szkoleń słynnej polskiej I Samodzielnej Brygady Spadochronowej gen. Stanisława Sosabowskiego, której siedzibą było Leith koło Edynburga. Są to mało znane karty w historii obu narodów, których żołnierze musieli uciekać do Wielkiej Brytanii (Szkocji), aby tam móc przygotować się do wyzwolenia swych krajów spod okupacji ${ }^{38}$.

\footnotetext{
34 AMSZ Z. 6, W. 76, T. 1093, pismo M. Rogalskiego do J. Olszewskiego z 2.06.1946 r., k. 1-2. 35 RA, UD 1940-49, E.10345, 20.20 Fremmede Statsborgeres St. Olavs Orden, 91 Polen, bd. I, pismo A. Danielsena z Poselstwa Norwegii w Warszawie, 23.03.1946 r.

36 RA, UD 1940-49, E.10345, 20.20 Fremmede Statsborgeres St. Olavs Orden, 91 Polen, bd. I, pismo G. Bulla z FD do UD - 21.09.1946 r.

37 RA, UD 1940-49, E.10345, 20.20 Fremmede Statsborgeres St. Olavs Orden, 91 Polen, bd. I, odręczna adnotacja G. Collina z 23.09.1946 r. na piśmie FD z 21.09.1946 r.

38 Szerzej: Sosabowski (2011).
} 
Tymczasem w kwestii odznaczeń odnotowujemy kolejne poczynania Rogalskiego, o czym świadczy jego pismo do MON z dnia 27 lipca 1946 roku, potwierdzające odbiór 9 odznaczeń Virtuti Militari, w tym 4 III klasy i 5 IV klasy, nadto 1 Krzyż Walecznych i 50 Srebrnych Medali Zasłużonym na Polu Chwały ${ }^{39}$. W sumie Rogalski otrzymał ich o połowę mniej, niż pierwotnie proponował. Poza tym widać wyraźnie, że władze w Warszawie nie spieszyły się z decyzjami w tej kwestii, brakuje też konkretnych danych co do terminu uroczystości wręczania odznaczeń, a przede wszystkim rangi tych odznaczeń. Najlepszym tego dowodem jest pismo Rogalskiego do MSZ z 28 września 1946 roku, w którym komunikował, że $\mathrm{w}$ rozmowie $\mathrm{z}$ szefem protokołu dyplomatycznego UD Collinem usłyszał, iż „odznaczenia proponowane dla Sekretarza Generalnego Pera Prebensena (Polonia Restituta III klasy) oraz dla niego i szeregu innych pracowników norweskiego MSZ są zbyt niskie i według obowiązujących protokolarnych przepisów powinny być wyższe o dwa stopnie". Dalej pisał, iż Collin motywował to w ten sposób, że on sam i Prebensen otrzymywali wyższe rangą odznaczenia. W dalszej części rozmowy, jak podkreślał Rogalski, Collin poinformował go, że dotyczy to także innych pracowników UD, stąd prosił go w drodze poufnej o podwyższenie rangi orderów. Nie miał natomiast zastrzeżeń co do proponowanych orderów Virtuti Militari II i III klasy dla generalicji norweskiej. Rogalski wyjaśniał dalej, że próbował tłumaczyć Collinowi, iż wszystko było zgodne z normami obowiązującymi w Polsce. Dodawał jednakże, że widzi potrzebę podniesienia rangi tych odznaczeń, choćby $\mathrm{z}$ tego powodu, że polska emigracja w Londynie zamierzała zadziałać w tym kierunku. Informował też, że dekoracja norweskich oficerów i żołnierzy odbędzie się 5 października $1946 \mathrm{roku}^{40}$. Jak zatem z powyższych ustaleń wynikało, odznaczeń doczekali się jedynie żołnierze i podoficerowie norwescy już nieżyjący, których listę znajdujemy w dokumentacji ( 25 żołnierzy i podoficerów wojsk lądowych i 20 marynarzy, w tym 7 oficerów marynarki). Zostali oni odznaczeni Srebrnym Medalem „Zasłużony na Polu Chwały”1. Sprawa zaś podwyższenia rangi odznaczeń dla generalicji i urzędników UD została podjęta dopiero w styczniu 1947 roku. Pismem z dnia 28 stycznia Rogalski zwracał się do Protokołu Dyplomatycznego MSZ o podwyższenie rangi orderów dla norweskich osobistości zgodnie z życzeniami norweskiego UD, dołączając doń wykaz ich nazwisk wraz

39 AMSZ, Z. 6, W. 76, T. 1093 Ordery, odznaczenia 1946, pismo M. Rogalskiego do płk. W. Komara z 27.07.1946 r., k. 8.

40 AMSZ, Z. 16 Protokół dyplomatyczny, W. 36 Norwegia, T. 618 Sprawy Protokolarne. Ordery, Odznaczenia (Polskie odznaczenia dla obywateli norweskich 1946-1949), pismo M. Rogalskiego z 28.09.1946 r. do Dyrektora A. Gubrynowicza, k. 27-28.

${ }^{41}$ AMSZ, Z. 16 Protokół dyplomatyczny, W. 36 Norwegia, T. 618 Sprawy Protokolarne. Ordery, Odznaczenia (Polskie odznaczenia dla obywateli norweskich 1946-1949), Wykaz podoficerów i żołnierzy norweskich odznaczonych srebrnym medalem „Zasłużonym na Polu Chwały” z 5.10.1946 r., k. 56-57. 
z zajmowanymi stanowiskami ${ }^{42} .12$ lutego przesłał także dla każdej z tych osób oddzielnie sformułowany wniosek, w którym zamieścił podstawowe dane osobowe o kandydacie wraz z zajmowanym stanowiskiem oraz zaproponował klasę Orderu Odrodzenia Polski - Polonia Restituta ${ }^{43}$. Jednakże w dalszej korespondencji Poselstwa RP z MSZ w Warszawie nie znajdujemy odpowiedzi na pismo Rogalskiego w tej kwestii. Ciąg dalszy tej historii odnaleźć można jednak w norweskiej dokumentacji archiwalnej z kwietnia 1947 roku. W notatce z 14 kwietnia tegoż roku Collin podkreślił, że ich propozycja z ubiegłego roku przydzielenia odznaczeń norweskim wojskowym i cywilom z UD w przypadku cywilów z UD do niczego nie doprowadziła. Collin pisał o tym następująco: „Mieli oni być udekorowani Polonia Restituta, ale władze polskie nie chciały przyznać takich stopni odznaczeń, które według międzynarodowych reguł były pożądane. $\mathrm{W}$ ten sposób zaproponowano radcy ds. zagranicznych (utenriksråd) Krzyż Komandorski II klasy!”. Należy tu wyjaśnić, że radca ds. zagranicznych w norweskim UD jest odpowiednikiem naszego wiceministra spraw zagranicznych. Pozostawałoby więc jedynie zastanowić się nad tym, czy polskie władze o tym wiedziały albo czy w ogóle chciały to wiedzieć. Istotne są dalsze informacje, które podawał Collin. Stwierdzał on, że 14 kwietnia 1947 roku, a więc w dniu, kiedy napisał swą notatkę, odwiedził go polski poseł i jego sekretarz. Poseł Rogalski miał mu zameldować, że 20 kwietnia wybiera się do Warszawy. Stwierdzić miał także, że tym razem właściwe ordery zostaną przypuszczalnie zaakceptowane przez stronę polską. Jednakże sekretarz Zalewski, który parę dni wcześniej wrócił z Warszawy, przywiózł wiadomość, że z polskiej strony oczekuje się rewanżu w tej kwestii, a okolicznością dla wzajemnego wręczania odznaczeń byłoby niedawne zakończenie prac nad umową handlową między Polską a Norwegią. Polacy życzyliby sobie wymiany odznaczeń przy okazji uroczystego podpisywania tej umowy przez obie strony, jak również rozszerzenia listy kandydatur Norwegów z 1946 roku (zawierającej siedem osób) o kolejne trzy osoby: dyrektora Departamentu Handlowo-Politycznego UD Johana Georga Raedera, posła Alfreda Danielsena z Poselstwa Norwegii w Warszawie i jego sekretarza Helge Akre. Rogalski i Zalewski poinformowali też Collina, że polską listę kandydatów do odznaczeń norweskich prześlą

42 AMSZ, Z.16 Protokół dyplomatyczny, W. 36 Norwegia, T. 619, pismo M. Rogalskiego z 28.01.1947 r. do A. Gubrynowicza, k. 9.

43 AMSZ, Z. 16 Protokół dyplomatyczny, W. 36 Norwegia, T. 619, Wnioski M. Rogalskiego z 12.02.1947 r. wystawione dla następujących norweskich urzędników - kandydatów do Orderu Odrodzenia Polski: P. Prebensen - były sekretarz UD, K. Hess-Larsen - wojewoda okręgu Nordland, G.F.Ch. Collin - szef Protokołu Dyplomatycznego UD; R. Andersen - dyrektor Departamentu Politycznego UD, T. Broch - poseł okręgu Nordland do Stortingu; E. Borch-Johnsen - naczelny lekarz okręgu Nordland, opiekował się polskimi żołnierzami spod Narviku, D. Knudsen - wicedyrektor Protokołu Dyplomatycznego UD. M. Rogalski proponował klasę I ww. orderu tylko dla P. Prebensena, dla kolejnych trzech kandydatów - klasę II, dla T. Brocha - kl. III i pozostałych dwóch - kl. IV, k. 14-26. 
$\mathrm{w}$ formie memorandum ${ }^{44}$. I rzeczywiście takie memorandum $\mathrm{z}$ datą 15 kwietnia 1947 roku już na drugi dzień dotarło do Collina. Zawarte jest w nim osiem nazwisk, na czele z ministrem spraw zagranicznych Zygmuntem Modzelewskim ${ }^{45}$. Wszystko byłoby z pewnością w porządku, gdyby nie fakt, że na liście tej Polacy sami nanieśli rangi i stopnie odznaczeń, na dodatek zawyżone!!! Collin, który pisał w tej sprawie oddzielną notatkę, skomentował to następująco: „na liście tej znajduje się sekretarz poselstwa Zalewski i nowo mianowany attaché handlowy - Wallach, którzy w swoim czasie będą i tak odznaczeni automatycznie, kiedy będą odchodzić ze swych stanowisk. Jednakże przydziela się im wyższy stopień odznaczenia (krzyż komandorski III klasy), niż przepisy na to zezwalają, a to należy poprawić" ${ }^{36}$. Z uwagi na tę potrzebę „poprawienia” polskich życzeń co do kategorii podanych odznaczeń i braku dalszych dokumentów, jak to zostało ostatecznie rozstrzygnięte, należy się domyślać, że z planowanej „akcji” odznaczeń z okazji podpisywania umowy handlowej między Polską a Norwegią wiosną 1947 roku zwyczajnie nic nie wyszło.

W dokumentacji polskiej znajdujemy jeszcze jeden „niezależny” sposób działania MSZ. Jak już wspomniano wcześniej, 20 kwietnia 1947 roku Rogalski miał udać się do Warszawy. W czasie jego pobytu w Warszawie sekretarz Poselstwa RP w Oslo Zalewski otrzymał nagle polecenie MSZ, aby to on w zastępstwie za Rogalskiego udał się do Narviku celem reprezentowania Poselstwa Polskiego podczas pobytu polskiej delegacji, a wizytę tę MSZ wyznaczyło na 28 kwietnia 1947 roku. Sprawę tę musiał Zalewski przedstawić natychmiast Collinowi. Było to bardzo dziwne dla Collina, tym bardziej, że uroczystości takie miały zwykle miejsce miesiąc później, 28 maja, a więc w dzień zwycięstwa pod Narvikiem. W tym dniu odbyły się przecież uroczystości rok wcześniej, o czym była już mowa. Jednakże władze norweskie dostosowały się do tej polskiej „inicjatywy” i zorganizowały w Narviku pobyt dla całej siedmioosobowej delegacji polskiej, w tym między innymi ministrów Jana Rabanowskiego i Adama Ostrowskiego. Na dworcu w Narviku prócz delegacji polskiej powitano licznych przedstawicieli strony norweskiej, między innymi pułkownika Ornulfa Dahla - dowódcę okręgu wojskowego w Narviku, odznaczonego w 1946 roku orderem Virtuti Militari IV klasy, a także burmistrza

44 UD 1940-49, Boks 10 320, 20.17.12 Dekorasjoner i anledning handelsforhandlinger med Polen, Notat av 14. april 1947 - Ordensutveksling med Polen, s. 1-2.

45 UD 1940-49, Boks 10 320, 20.17.12 Dekorasjoner i anledning handelsforhandlinger med Polen, Aide-mémoire fra Polsk Legasjon i Oslo av 15. april 1947. Oprócz Z. Modzelewskiego memorandum to wymienia następujące osoby: J. Olszewski - wiceminister spraw zagranicznych, J. Berman z Biura politycznego PPR, A. Gubrynowicz - szef Protokołu Dyplomatycznego MSZ, A. Zalewski - sekretarz Poselstwa RP w Oslo, L. Wallach - attaché ds. handlowych Poselstwa RP w Oslo, dr T. Chromecki - wicedyrektor Departamentu Politycznego MSZ i F. Janiszewska - dyrektor biura w gabinecie ministra spraw zagranicznych.

46 UD 1940-49, Boks 10 320, 20.17.12 Dekorasjoner i anledning handelsforhandlinger med Polen, Notat - Ordensutveksling med Polen av 16. april 1947. 
Narviku Alfreda Nilsena oraz wielu innych wysokich rangą wojskowych ${ }^{47}$. Rząd norweski wykazał się w ten sposób poparciem dla działań TRJN, nawet w narzuconym przez polski MSZ terminie uroczystości w Narviku. Nie zaprosił też przedstawicieli polskiego rządu emigracyjnego w Londynie, aby nie drażnić Moskwy i nie ryzykować międzynarodowego skandalu.

Należy też podkreślić, że ta nagła wizyta polskiej delegacji jest pierwszym i nieostatnim dowodem arbitralnego sposobu działania polskich władz, które nie liczyły się z obowiązującymi zasadami, nie interesowało ich, kiedy i jakie rocznice powinny być obchodzone. Najistotniejszy w tym wszystkim był efekt propagandowy. Z opisanej wyżej nagłej wizyty w Norwegii wynika również, że poseł Rogalski został arbitralnie wymanewrowany. Był bowiem dla MSZ osobą posiadającą zbyt wiele pozytywnych i wartościowych kontaktów, a więc tym samym niebezpieczną dla reżimu prosowieckiego. Rogalski jeszcze w czerwcu 1947 roku w piśmie poufnym do Olszewskiego pisał: „W związku z projektowaną od dawna wymianą orderów pomiędzy Polską a Norwegią zaznaczyć muszę, że sfinalizowanie tej sprawy staje się rzeczą pilną. Opóźniona wymiana orderów może wiele utracić ze swego znaczenia”. Aby jeszcze bardziej podkreślić taką potrzebę, zwrócił uwagę na dużą aktywność Czechosłowacji w działalności propagandowej. Podkreślił, że Czesi w ostatnim czasie zasypywali Norwegię swoimi filmami, nutami, wydawnictwami, audycjami radiowymi, rozwijali wymianę kulturalną, w tym organizowali wycieczki do Norwegii. Informował też, że poseł czeski w Oslo mówił mu, iż Czechosłowacja zamierza odznaczyć króla Haakona VII orderem Wielkiej Wstęgi Białego Lwa ze Złotym Łańcuchem, a także zamierzała przeprowadzić szerszą wymianę orderów z rządem norweskim. Stąd stwierdzał: „Polska nie powinna pozostać w tyle i nie powinna utracić swych wpływów, które obecnie są nieporównanie większe niż Czechosłowacji. W tym celu proponowałbym odznaczenie króla Haakona VII Wielką Wstęgą Virtuti Militari jako bohatera II wojny światowej”. Jako uzasadnienie podawał bardzo silną pozycję króla, który cieszył się powszechnym szacunkiem, nie tylko wśród swoich obywateli, ale poza granicami kraju. I miał tu na myśli zarówno Związek Sowiecki, jak i Polskę. Wskazywał też jego więzi pokrewieństwa z monarchią brytyjską oraz podkreślał jego antyniemieckie nastawienie $^{48}$. Jednakże, jak wynika z dokumentów Protokołu Dyplomatycznego, polski MSZ nie skorzystał z dobrych rad Rogalskiego, o czym świadczy przesłane Poselstwu przez MSZ w lipcu 1946 roku dziesięciu odznaczeń (Uchwała Prezydium $K R N$...), z których tylko dwa przyznano konsulom honorowym w Oslo - Christia-

\footnotetext{
47 AMSZ, Z. 6, W. 76, T. 1097 - Norwegia 3943. Tablice, pomniki wojenne (uroczystości polskie w Narviku), Pismo poufne sekretarza Poselstwa A. Zalewskiego z 5.05.1947 r. do wicedyrektora Departamentu Politycznego MSZ dr. T. Chromeckiego, k. 2-3.

48 AMSZ, Z. 16, W. 36, T. 618, pismo poufne M. Rogalskiego do J. Olszewskiego z 11.06.1947 r., k. 4-5.
} 
nowi Strandowi i w Stavanger - Karlowi M. Torgrimsenowi, pozostałe zaś znajdowały się nadal w Poselstwie ${ }^{49}$. Kolejny dowód na to, że MSZ uznało Rogalskiego za persona non grata, to decyzja o jego odwołaniu z dniem 30 listopada 1947 roku ze stanowiska Posła Nadzwyczajnego i Ministra Pełnomocnego RP w Oslo i Reykja$v \mathrm{ku}^{50}$. Na jego miejsce powołano dotychczasowego I sekretarza Ambasady Polski w Waszyngtonie Józefa Giebułtowicza, który przybył do Oslo 21 marca 1948 roku.

Podsumowując, należy podkreślić, że uruchomienie polskiej placówki dyplomatycznej w Oslo tuż po zakończeniu II wojny światowej nie było planowane przez nowe komunistyczne władze w Warszawie. Nastąpiło to dopiero wówczas, gdy do rządu warszawskiego dotarło, że w tej sprawie aktywny jest polski rząd emigracyjny w Londynie. Dodatkowym bodźcem były również zabiegi dyplomatyczne strony norweskiej zmierzające do tego, aby w Oslo jak najszybciej uruchomiono stałą placówkę dyplomatyczną Polski. Decydowały o tym nie tylko względy prestiżowe, ale i gospodarcze, w tym głównie sprawa importu polskiego węgla. Nadto trudny dla obu stron problem - przy czym dla TRJN w Warszawie zupełnie nieznany - stanowiła repatriacja ogromnej rzeszy Polaków z Norwegii. Należy jednak podkreślić, że była to zarazem jedyna taka sprawa, którą dzięki późnemu uruchomieniu polskiej placówki mogli sprawnie rozwiązać znajdujący się w Norwegii oficerowie łącznikowi polskiego rządu emigracyjnego. Uczynili to spokojnie, zgodnie z wolą repatriowanych i bez stosowania jakiegokolwiek przymusu. Poseł Rogalski i sekretarz Zalewski, którzy przybyli do Oslo dopiero w kwietniu 1946 roku, nie chcieli lub wręcz woleli nie włączać się w te sprawy, bowiem mogli mieć świadomość tego, że nie będą w stanie rozwiązać problemu repatriacji do końca tak, aby pozostałych około 1100 Polaków związanych już ze społecznością norweską zmusić do wyjazdu do Polski. Znacznie łatwiej udało się im spełnić wymogi propagandy komunistycznej w przypadku ogromnie popularnych uroczystości narwickich. Swoiste zrządzenie losu pomogło im bowiem wyeliminować emigranckich przedstawicieli z udziału w uroczystościach narwickich w maju 1946 roku. Stąd Rogalski mógł zaprezentować się tam osobiście wraz z małżonką i sekretarzem Poselstwa. Jednakże w kwestii wymiany odznaczeń między oboma krajami usiłowania Rogalskiego zmierzające do spełnienia próśb norweskiego UD o podwyższeniu stopnia przyznawanych odznaczeń na nic się nie zdały. Dominacja w tej sprawie polskiego MSZ była na tyle arbitralna, że Rogalski został uznany za osobę niewypełniającą poleceń MSZ, stąd wykluczono go z udziału w uroczystościach narwickich w kwietniu 1947 roku. Nadto ten manewr MSZ, jak również to, że Rogalski miał zbyt wiele dobrych kontaktów dyplomatycznych, co najwyraźniej nie odpowiadało władzom komunistycznym, sprawiło, że zaledwie po półtora roku swej działalności dyplomatycznej został odwołany ze stanowiska posła RP w Oslo.

\footnotetext{
49 AMSZ, Z. 16, W. 36, T. 618, pismo J. Giebułtowicza z 21.06.1948 r. do MSZ, Protokół Dyplomatyczny, k. 7-8.

50 AMSZ, Z. 16, W. 36, T. 621, pismo prezydenta RP do M. Rogalskiego z 25.11.1947 r., k. 18.
} 
Bibliografia

Źródła archiwalne

Archiwum Ministerstwa Spraw Zagranicznych (AMSZ)

Departament polityczny MSZ:

Zespół (Z) 6, Wiązka (W) 76, Teczka (T): 1090, 1091, 1092, 1903, 1094, 1095.

Z. 6, W. 76, T. 1096 i T. 1103 Norwegia 242, Raporty i notatki polityczne Poselstwa RP w Oslo.

Z. 6, W. 76, T. 1097, Norwegia 3943, Tablice, pomniki wojenne (uroczystości polskie w Narviku).

Z. 6, W. 76, T. 1098, Norwegia 531, Opieka nad deportowanymi i jeńcami (sytuacja w obozach polskich).

Z. 6, W. 76, T. 1100, Norwegia 08, Sprawozdania z rozmów 1947-1948.

Z. 6, W. 76, T. 1102, Norwegia 242, Charakterystyka partii politycznych.

Z. 16 Protokół dyplomatyczny, W. 36 Norwegia, T. 618, 619 i 621 - Ordery, odznaczenia - sprawy protokolarne 1946-1949.

Nabytek 24.97, W. 17, Karta personalna M. Rogalskiego.

\section{Riksarkivet Oslo (RA)}

Utenriksdepartemetet (UD) 1940-49

Eske (E) 10165, 10.21/91 Polens sendemann i Norge.

E. 10345, 20.20, Fremmede Statsborgeres St. Olavs Orden, 91 Polen, bd I.

E. 10320, 20.17, Dekorasjon i anledning handelsforhandlinger med Polen.

\section{Opracowania}

Denkiewicz-Szczepaniak, E. (2012). Misja handlowo-dyplomatyczna Rolfa Andvorda w Polsce w sierpniu i wrześniu 1945 roku. Zapiski Historyczne 77 (3): 23-50.

Denkiewicz-Szczepaniak, E. (2014). Problem repatriacji Polaków z Norwegii (maj 1945 - kwiecień 1946 roku). Zapiski Historyczne 79 (1): 37-61.

Denkiewicz-Szczepaniak, E. (2018a). Establishing diplomatic relations between Poland and Norway in the years 1945-1946. Studia Maritima 31: 207-210.

Denkiewicz-Szczepaniak, E. (2018b). Polska siła robocza w Organizacji Todta w Norwegii i Finlandii w latach 1941-1945. Gdańsk: Wydawnictwo Uniwersytetu Gdańskiego.

Encyklopedia Powszechna PWN. (2009). T. 26. Warszawa: Wydawnictwo Naukowe PWN.

Jahr, I. (2013). Hasło: Charles Ulric Bay. W: A.M. Godal (red.). Store norske leksikon. Oslo: Norsk nettleksikon.

Sosabowski, S. (2011). Najkrótszą drogą. Łomianki: Wydawnictwo LTW.

Uchwała Prezydium Krajowej Rady Narodowej z dnia 11 lipca 1946 r. o nadaniu odznaczeń obywatelom szwedzkim i norweskim za działalność charytatywną, życzliwy stosunek do Poselstwa R.P. w Oslo, zasługi na polu zbliżenia kulturalnego, zasługi na polu stosunków gospodarczych polsko-szwedzkich, opiekę nad jednostkami marynarki polskiej internowanej w Szwecji oraz za pomoc udzielaną polskim organizacjom konspiracyjnym w czasie okupacji, http://prawo.sejm.gov.pl/isap.nsf/download.xsp/WMP19470060009/O/M19470009 (dostęp: 28.01.2020). 